\title{
Immunoglobulin Light Chain, Lambda
}

National Cancer Institute

\section{Source}

National Cancer Institute. Immunoglobulin Light Chain, Lambda. NCI Thesaurus. Code C16719.

Immunoglobulin Light Chain Lambda is one of two Ig light chain types. Each Ig molecule is typically composed of two heavy chains and two light chains but Ig lambda light chains contain a variable and a constant region. Lambda light chains are encoded by multiple V, J, and $\mathrm{C}$ gene segments, which are separated in the genomes of cells undifferentiated with regard to antibody gene expression. During differentiation of an activated (lambda-type) antibody-producing B-cell, diversity in the lambda light chain $\mathrm{V}$ region arises from variable recombination of lambda $\mathrm{V}$ genes with lambda J genes and somatic point mutation, which plays a major role in antibody diversity. (from OMIM 147220 and $\mathrm{NCl}$ ) 